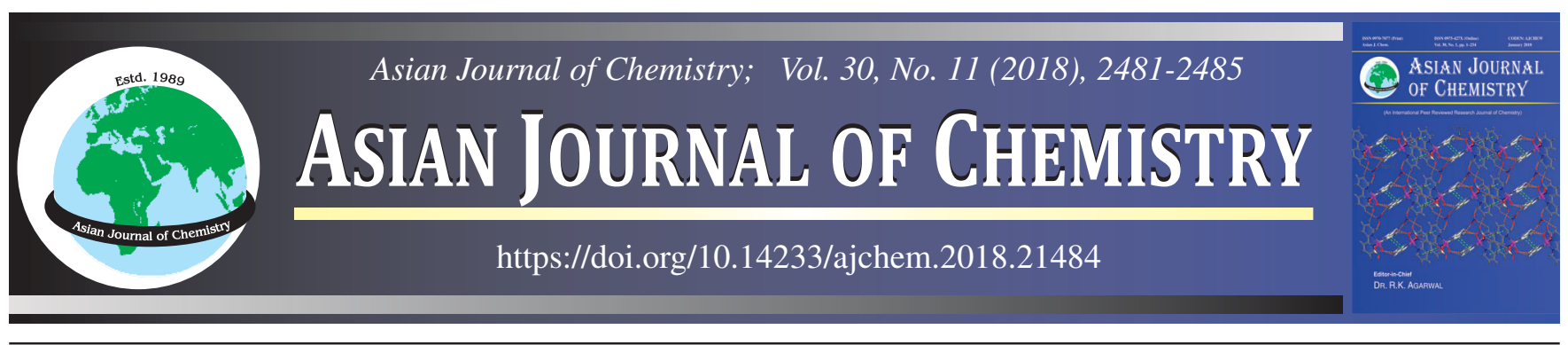

\title{
Study of Exhaust Emissions from Different Fuels based Vehicles in Lahore City of Pakistan
}

\author{
Muhammad Tahir Butt ${ }^{1}$, Naeem Abbas ${ }^{1, *}$, Farah Deeba $^{1}$, Javed Iqbal $^{1}$, Naqi Hussain ${ }^{2}$ and Rauf Ahmed Khan ${ }^{1}$
}

${ }^{1}$ Centre for Environmental Protection Studies, Pakistan Council of Scientific \& Industrial Research, Lahore, Pakistan

${ }^{2}$ Applied Chemistry Research Centre, Pakistan Council of Scientific \& Industrial Research, Lahore, Pakistan

*Corresponding author: E-mail: naeemchemist@gmail.com

Lahore is a mega city of Pakistan located in South Asia having more than 1.5 million populations. Motor vehicles are the major sources of pollution in this city. This study is focused on the measurement of air pollution levels due to congested traffic in Lahore city. The average results of two-wheeler and four-wheeler vehicles using petrol as fuel showed that the level of $\mathrm{CO}_{2}$ was in the range of 2.20-8.80 $\%, \mathrm{NO}_{2}$ from $0.00-83.33 \mathrm{ppm}, \mathrm{SO}_{2} 99.67-799.33 \mathrm{ppm}$ and hydrocarbons in the range of 77.33-550 ppm. Vehicles using compressed natural gas as fuel showed $\mathrm{CO}_{2}$ was in the range 1.44-9.80\%, $\mathrm{NO}_{2}, 10.22-25.37 \mathrm{ppm}, \mathrm{SO}_{2}$ zero emissions and hydrocarbons 4.36-13.66 $\mathrm{ppm}$. Vehicle exhaust emission data showed that Lahore city is exposed to high concentration of $\mathrm{CO}_{2}, \mathrm{NO}_{\mathrm{x}}$ and $\mathrm{SO}_{\mathrm{x}}$. The overall results of study showed that compressed natural gas is more environment friendly fuel as compared to petrol. However, pollution level can considerably improve by introduction of large-scale compressed natural gas vehicles in Lahore city.

Keywords: Vehicle emissions, Flue gas analysis, Air emissions, Air quality standards.

\section{INTRODUCTION}

Lahore is a big city of Pakistan in the south Asia, having a fast growth in urban population and industrial development in recent years. Air pollution has increased due to these developments in last decade. Air pollution in Lahore city, Pakistan is reported to be very serious and highly injurious to public health.

It is revealed that the traffic congestion, fuel quality are the main reasons of air pollution in Lahore city. To control air pollution level, compressed natural gas $(\mathrm{CNG})$ in motor vehicles at large scale has introduced in Lahore city as well as in Pakistan being low-cost fuel. Decline in air quality is a major environmental problem in several large urban centers in developed and developing countries. In our society, quality of life is significantly measured by the consumption of electricity or by the use of car. In vehicles and electricity generation mostly, fossil fuels are used. Due to the burning of these fossil fuels dangerous chemicals and particulate matter are produced as a part into atmosphere due to inadequate combustion of fuels causing serious air pollution, effecting human health. The vehicular exhaust affects our valuable historical places, heritage and environment. Topographical and weather conditions affect the transportation of these pollutants in ambient air. Mostly people spend their time indoor and pollutants concentration may be build up in a closed environment, the greater health risk to expose to indoor air pollution than outdoor. Worldwide, about 3.7 million deaths were indorsed due to ambient air pollution in 2012 [1]. Due to $\mathrm{PM}_{10}$ and $\mathrm{PM}_{2.5} 88 \%$ human deaths were noticed in low and middle-income areas and this large burden of diseases were associated with particulate matter. The fine particles of particulate matter generated from vehicular emissions have been held responsible for cancer, respiratory and cardiovascular diseases [2,3]. Recent air quality studies in Asian region have shown that various air pollution levels are in excess of WHO guidelines for ambient air quality standards in high income countries [4-6]. Motor vehicles are the most rapidly growing source of air pollutants (e.g. particulate matter, hydrocarbons, carbon monoxide and oxides of nitrogen) in Lahore city. In Pakistan, industrial sector and vehicular traffic is the leading contributor towards poor air quality.

In automobile sector such as buses, trucks and jeeps \& cars registered growth of $81.95,68.53,41.68$ and $29.73 \%$, respectively. The number of total vehicles in the country has

This is an open access journal, and articles are distributed under the terms of the Creative Commons Attribution-NonCommercial 4.0 International (CC BY-NC 4.0) License, which allows others to copy and redistribute the material in any medium or format, remix, transform, and build upon the material, as long as appropriate credit is given and the new creations are licensed under the identical terms. 
seen an average growth rate of large and small-scale manufacturing $133.9 \%$ during 2015-2016 Pakistan Economic Survey [6]. In Punjab the total number of registered vehicles was 7,483,860 in 2010. The highest growth rate of $16 \%$ among all cities of Punjab, the number of vehicles was estimated to be 2,400,000 in 2010 [7-9]. As a result of this colossal traffic burden on roads in urban areas of the country are suffering from deprived air quality along with increased frequency of respirational allergies [10,11]. Overall, the state of ambient air quality in urban areas of Pakistan is shocking. The PM (particulate matter) with various other pollutants levels are several times higher than Environmental Protection Authority (EPA) standards and WHO guidelines. It has been observed from last few years that a marked increase in number of automobiles along with small scale industries both are contributing to the deterioration of air quality [11]. High concentrations of fine and ultrafine particles in an urban environment, especially around roads, can have ample health effects for daily travelers as well as to urban residents [12-14].

Combustion process: In internal combustion process the fuel combustion takes place inside the cylinder of engine. The characteristic of the internal combustion engine is that combustion of fuel takes place along with conversion of heat energy into mechanical work inside the cylinder. Internal combustion is known for high efficiency and low operating cost, compactness and light weight. Emissions from internal combustion engine are the main source of air pollution [15].

Fuel + Air $\longrightarrow$ Carbon dioxide + Water + Unaffected $\mathrm{N}_{2}(1)$

Fuel + Air + Nitrogen oxides +

Carbon monoxide + Carbon dioxide + Water

Eqns. 1 and 2 describes the perfect and typical engine combustion reactions, respectively.

Stoichiometry of combustion means composition of the reactants of a combustible mixture (fuel and air) and the composition of the products. These relations depend only in the conservation of mass of each chemical element in the reactants.

The overall complete combustion equation (eqn. 3):

$\mathrm{C}_{\mathrm{a}} \mathrm{H}_{\mathrm{b}}+\left(\mathrm{a}+\frac{\mathrm{b}}{4}\right)\left(\mathrm{O}_{2}+3.733 \mathrm{~N}_{2}\right)=\mathrm{aCO}_{2}+\frac{\mathrm{b}}{2} \mathrm{H}_{2} \mathrm{O}+3.733\left(\mathrm{a}+\frac{\mathrm{b}}{4}\right) \mathrm{N}_{2}(3)$

If, the fuel is octane $\mathrm{C}_{8} \mathrm{H}_{18}$; Combustion equation becomes:

$\mathrm{C}_{8}+12.5\left(\mathrm{O}_{2}+3.733 \mathrm{~N}_{2}\right)=8 \mathrm{CO}_{2}+9 \mathrm{H}_{2} \mathrm{O}+47.16 \mathrm{~N}_{2}(4)$

In moles:

$$
\begin{gathered}
1+12.5\left(1+3.773 \mathrm{~N}_{2}\right)=8+9+47.16 \\
1+59.66=64.16
\end{gathered}
$$

Relative mass:

$114.15+59.66 \times 28.96=$

$$
8 \times 44.01+9 \times 18.02+47.16 \times 28.16
$$

$114.15+1727.8=1842.3$

Per unit mass fuel: $1+15.14=16.14$

For stoichiometric combustion, $1 \mathrm{~mol}$ of fuel requires $59.66 \mathrm{~mol}$ of air and produces $64.16 \mathrm{~mol}$ of products. The stoichiometric $(\mathrm{A} / \mathrm{F})_{\mathrm{S}}$ is 15.14 and $(\mathrm{F} / \mathrm{A})$ is 0.0661 .

Emissions from automobiles contribute significantly two third of air pollution in urban areas.
Main pollutants emitted from the automobiles using gasoline as fuel are follows:

(a) Carbon monoxide is a colourless and odourless gas heavier than air, toxic to the environment.

(b) Hydrocarbon compounds containing hydrogen and carbon along with various volatile organic compounds.

(c) Oxides of nitrogen $\left(\mathrm{NO}_{\mathrm{x}}\right)$, which contains nitrogen oxide, nitrogen dioxide, nitrogen trioxide, etc.

(d) Lead is also emitted from automobile emissions, which are dangerous for environment as well as to the human health.

In present study an effort is going to be made for the assessment of air quality in Lahore city and recommendations for the air pollution reduction, which will reduce the health costs. So, the emission analysis and reduction techniques should be implementing in urban centers in Pakistan to reduce vehicular exhaust emission.

\section{EXPERIMENTAL}

In this study different parameters of vascular emissions like temperature, oxygen, carbon dioxide, carbon monooxide, oxide of nitrogen, oxides of sulfur and hydrocarbons of diverse types of vehicles running in Lahore, Pakistan were measured by using MRU Delta 2000 Germany [15]. The collected data were statistically analyze to comparing with the standard data. After analysis, conclusion was drawn about the present air quality situation of Lahore city of Pakistan.

Calibration and working of MRU Delta 2000 Germany: The system was switched on and was calibrated in the ambient air. The vehicle was in a start position $30 \mathrm{~min}$ before measuring the exhaust emission of vehicle. The probe of instrument was inserted and fixed in the emission pipe of the vehicle. Then enter button on instrument was pressed for readings displayed on the screen of instrument till the maximum reading was attained and the instrument was calibrated before each reading. Emission monitoring system Delta 2000 Germany is a selfcalibrated system. The highest temperature values displayed on the screen of instrument. The probe of instrument was removed from measurement point and system was purged in ambient air, until system displayed 0 reading for each component or oxygen sensor showed $21 \%$ reading then system is ready to be switch off [16].

\section{RESULTS AND DISCUSSION}

The study was contested on the vehicular emissions using different fuels. The average emission results (Table-1) shows the average of compressed natural gas $(\mathrm{CNG})$ emissions. The WHO guide line for air pollution limits for residential areas and traffic intersections are also presented in Table-2. The motor cycles used in this study were 4-stroke and cars used in this study were 6 cylinders. For this, three observations were taken for each vehicle for each fuel used. In case study for compressed natural gas vehicles, one compressed natural gas vehicle was used for observations and 10 observations were recorded. The emission data from engine using compressed natural gas as a fuel is presented in Table-1.

The average emission results indicated that maximum emission of motor cycle and cars using petrol as compared 


\begin{tabular}{|c|c|c|c|c|c|c|}
\hline \multirow{3}{*}{ Parameter } & \multicolumn{6}{|c|}{$\begin{array}{c}\text { TABLE-1 } \\
\text { AVERAGE EMISSIONS DATA FOR MOTOR CYCLE AND CARS }\end{array}$} \\
\hline & \multicolumn{2}{|c|}{ Motor cycle } & \multicolumn{2}{|c|}{ Cars } & \multicolumn{2}{|c|}{ Cars using CNG } \\
\hline & Min. & Max. & Min. & Max. & Min. & Max. \\
\hline Temp-gas $\left({ }^{\circ} \mathrm{C}\right)$ & 38.80 & 42.23 & 136.40 & 162.77 & 138.42 & 166.79 \\
\hline Temp-ambient $\left({ }^{\circ} \mathrm{C}\right)$ & 34.27 & 35.23 & 34.67 & 38.80 & 34.66 & 39.70 \\
\hline Oxygen $(\%)$ & 14.27 & 17.43 & 13.63 & 20.63 & 14.33 & 20.60 \\
\hline Carbon dioxide (\%) & 2.80 & 8.80 & 1.33 & 8.70 & 1.44 & 9.80 \\
\hline Carbon mono oxide (\%) & 6204.33 & 7789.33 & 794.67 & 8022.33 & 64.63 & 82.39 \\
\hline Losses $(\%)$ & 0.73 & 1.23 & 0.27 & 6.77 & 0.27 & 5.27 \\
\hline Efficiency (\%) & 98.60 & 99.27 & 93.23 & 99.73 & 92.33 & 94.73 \\
\hline Exc. Air $(\%)$ & 4.11 & 5.65 & 2.88 & 8.41 & 3.68 & 9.43 \\
\hline Nitrogen oxide (ppm) & 0.00 & 83.33 & 24.67 & 130.67 & 10.63 & 25.37 \\
\hline Sulfur oxide (ppm) & 99.67 & 791.33 & 24 & 472.67 & 0.00 & 0.00 \\
\hline Hydrocarbons (ppm) & 77.33 & 550 & 188.33 & 505 & 4.36 & 13.66 \\
\hline
\end{tabular}

cars using $\mathrm{CNG}$ as shown in Fig. 1. The hydrocarbon concentration in CNG cars were also very low as compared to motor cycle and cars using petrol.

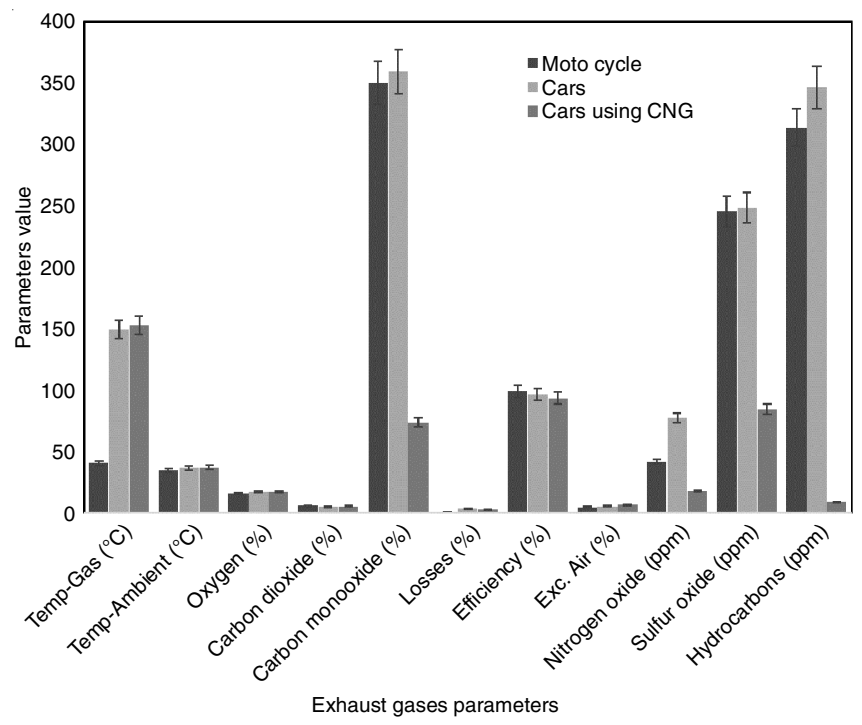

Fig. 1. Average emissions data for motor cycle, cars and cars using CNG

The toxic emissions in case of cars emissions using petrol and diesel are $\mathrm{NO}_{2}, \mathrm{NO}_{3}$ and $\mathrm{SO}_{3}$ along with $\mathrm{CO}_{2}$ and $\mathrm{CO}$. The maximum limit defined in the WHO guide line is $150 \mathrm{ppm}$ and in residential area is $42 \mathrm{ppm}$ and in traffic intersections limit is $110 \mathrm{ppm}$ for $\mathrm{NO}_{2}$ emissions but in this study the recorded observations show that the value of petrol (Table-2) for $24 \mathrm{~h}$ average air pollution [1] compressed natural gas using as fuel. For motor cycles emissions are 0.00 to $83.33 \mathrm{ppm}$, for vehicles using petrol as a fuel are 24.67 to $130.67 \mathrm{ppm}$ and results for vehicles using compressed natural gas as fuel are $0.00 \mathrm{ppm}$. While motor cycles and vehicles using petrol as fuel showed $\mathrm{SO}_{2}$ results are 99.67 to $791.33 \mathrm{ppm}$ in case of motorcycles and for vehicles/cars using petrol as fuel showed $\mathrm{SO}_{2}$ results are 24-472.67 ppm and vehicles using compressed natural gas as a fuel showed no $\mathrm{SO}_{2}$ emissions and limits for $\mathrm{SO}_{2}$ in WHO guide lines are defined as maximum $125 \mathrm{ppm}$ and $80 \mathrm{ppm}$ in residential areas and $20 \mathrm{ppm}$ in traffic inter sections. In case of motorcycle the maximum limit for $\mathrm{SO}_{2}$ is $125 \mathrm{ppm}$ while motorcycles show maximum average for $\mathrm{SO}_{2}$ is $791.33 \mathrm{ppm}$ (Table-1) and which is 641.33 ppm over the WHO guide lines limit (Table-2). In case of vehicles/cars using petrol as a fuel shows the $\mathrm{SO}_{2}$ results $24-472.33 \mathrm{ppm}$. $\mathrm{SO}_{2}$ is 322.33 ppm over the WHO guidelines in case of vehicles/cars and in case vehicles using compressed natural gas $(\mathrm{CNG})$ show no $\mathrm{SO}_{2}$ emissions. All these results show that $\mathrm{NO}_{2}$ and $\mathrm{SO}_{2}$ emissions are more than the defined limits in WHO guide lines, which requires the strict monitoring of fuel along with the fitness of motorcycles and cars. While there is no limit for $\mathrm{CO}$ and $\mathrm{CO}_{2}$ whereas, $\mathrm{CO}_{2}$ also plays its part as global warming by damaging the ozone layer damaging which also pollutes the environment. Compressed natural gas is low-cost than the petrol as a fuel and the maintenance cost of vehicles is lower as compared to petrol using as fuel.

\begin{tabular}{cccc}
\multicolumn{4}{c}{ TABLE-2 } \\
24 h AVERAGE AIR POLLUTION GUIDELINE [Ref. 1]
\end{tabular}

The vehicles using CNG emits 20-30\% fewer greenhouse gas emissions, emissions from vehicle can have global warming impact $1-3 \%$ due to $\mathrm{CO}_{2}$ from a given vehicles $[17,18]$. Motor vehicles with different engine types emit different pollutants for example two stroke and four stroke engines show very poor performance in emitting $\mathrm{CO}_{2}$ and four stroke engines shows bad performance in emitting $\mathrm{CO}$ emissions, two strokes in hydrocarbon and 4-stroke in $\mathrm{NO}_{2}, \mathrm{NO}$ and $\mathrm{SO}_{2}$ shows poor emission's. These emissions depend on the fuel type [19].

The traffic in Lahore is increasing at alarming proportion. According to the Excise and Taxation Department Punjab, there were 1,241,224 vehicles registered in Lahore till the year 2008. This number included: 379,481 motor cars, 740,022 motorcycles, 45,270 rickshaws and 35,101 pickups. Main problem associated with the increased traffic in Lahore is the increasing pollution level in the city. Though the industry is also contributing in air pollution of Lahore but traffic pollution is the major culprit. Vehicles' share in the pollution in Lahore is $70 \%$ and the two-stroke rickshaws alone are responsible for $40 \%$ of the total pollution. More than $80 \%$ of air pollutants 
TABLE-3

DESCRIPTIVE STATISTICS OF DIFFERENT PARAMETERS OF MOTOR CYCLES OF DIFFERENT BRANDS

\begin{tabular}{|c|c|c|c|c|c|c|c|c|}
\hline \multirow{2}{*}{ Parameters } & \multirow{2}{*}{$\begin{array}{l}\text { Min. } \\
\text { Stats. }\end{array}$} & \multirow{2}{*}{$\begin{array}{l}\text { Max. } \\
\text { Stats. }\end{array}$} & \multicolumn{2}{|c|}{ Mean } & \multirow{2}{*}{$\begin{array}{c}\text { Std. Dev. } \\
\text { Stats. }\end{array}$} & \multirow{2}{*}{$\begin{array}{c}\text { Variance } \\
\text { Stats. }\end{array}$} & \multirow{2}{*}{$\begin{array}{c}\text { Skewness } \\
\text { Stats. }\end{array}$} & \multirow{2}{*}{$\begin{array}{c}\text { Kurtosis } \\
\text { Stats. }\end{array}$} \\
\hline & & & Stats. & Std. Error & & & & \\
\hline Temp. gas $\left({ }^{\circ} \mathrm{C}\right)$ & 38.7 & 44.4 & 40.773 & 0.51 & 2.007 & 4.031 & 1.021 & 0.231 \\
\hline Temp. ambient $\left({ }^{\circ} \mathrm{C}\right)$ & 34.2 & 35.3 & 34.753 & 0.085 & 0.329 & 0.108 & 0.035 & 0.282 \\
\hline $\mathrm{O}_{2}(\%)$ & 13.7 & 17.6 & 16.033 & 0.281 & 1.092 & 1.192 & -.676 & 0.220 \\
\hline $\mathrm{CO}_{2}(\%)$ & 2.7 & 8.9 & 4.640 & 0.579 & 2.242 & 5.030 & 1.371 & 0.344 \\
\hline $\mathrm{CO}(\%)$ & 4655 & 7790 & 6883.67 & 92.77 & 46.610 & 55.238 & -1.747 & 5.683 \\
\hline Losses $(\%)$ & 0.7 & 1.7 & 0.973 & 0.085 & 0.332 & 0.111 & 1.035 & 0.264 \\
\hline Efficiency (\%) & 98.3 & 99.3 & 99.040 & 0.082 & 0.318 & 0.101 & -1.160 & 0.343 \\
\hline Exc. $(\%)$ & 4.10 & 5.68 & 4.5660 & 0.149 & 0.577 & 0.333 & 1.471 & 0.577 \\
\hline $\mathrm{NO}_{2}(\mathrm{ppm})$ & 10 & 107 & 31.67 & 7.681 & 29.748 & 24.95 & 1.422 & 1.893 \\
\hline $\mathrm{H}_{2} \mathrm{~S}(\mathrm{ppm})$ & 79 & 793 & 508.60 & 60.456 & 34.145 & 54.82 & 0.876 & 0.034 \\
\hline $\mathrm{HCs}(\mathrm{ppm})$ & 70 & 163 & 102.00 & 7.919 & 30.669 & 40.57 & 0.985 & 0.225 \\
\hline
\end{tabular}

TABLE-4

DESCRIPTIVE STATISTICS OF DIFFERENT PARAMETERS OF CARS USING DIFFERENT FUELS

\begin{tabular}{|c|c|c|c|c|c|c|c|c|}
\hline \multirow{2}{*}{ Parameters } & \multirow{2}{*}{$\begin{array}{l}\text { Min. } \\
\text { Stats. }\end{array}$} & \multirow{2}{*}{$\begin{array}{l}\text { Max. } \\
\text { Stats. }\end{array}$} & \multicolumn{2}{|c|}{ Mean } & \multirow{2}{*}{$\begin{array}{l}\text { Std. Dev. } \\
\text { Stats. }\end{array}$} & \multirow{2}{*}{$\begin{array}{c}\text { Variance } \\
\text { Stats. }\end{array}$} & \multirow{2}{*}{$\begin{array}{c}\text { Skewness } \\
\text { Stats. }\end{array}$} & \multirow{2}{*}{$\begin{array}{c}\text { Kurtosis } \\
\text { Stats. }\end{array}$} \\
\hline & & & Stats. & Std. Error & & & & \\
\hline Temp. gas $\left({ }^{\circ} \mathrm{C}\right)$ & 134.8 & 172.6 & 147.27 & 2.14 & 11.76 & 38.39 & 1.06 & -0.135 \\
\hline Temp. ambient $\left({ }^{\circ} \mathrm{C}\right)$ & 34.6 & 36.9 & 35.35 & 0.12 & 0.68 & 0.466 & 0.74 & -0.451 \\
\hline $\mathrm{O}_{2}(\%)$ & 14.5 & 20.9 & 17.26 & 0.26 & 1.44 & 2.078 & 0.40 & 1.12 \\
\hline $\mathrm{CO}_{2}(\%)$ & 1.3 & 8.8 & 3.354 & 0.36 & 1.98 & 3.93 & 2.03 & 3.56 \\
\hline $\mathrm{CO}(\%)$ & 793 & 7199 & 4179.47 & 64.41 & 43.71 & 86.05 & -0.15 & -1.66 \\
\hline Losses $(\%)$ & 0.4 & 6.8 & 2.353 & 0.39 & 2.17 & 4.711 & 0.88 & -0.65 \\
\hline Efficiency (\%) & 93.2 & 99.6 & 97.65 & 0.39 & 2.16 & 4.68 & -0.89 & -0.62 \\
\hline Exc. $(\%)$ & 3.33 & 8.75 & 5.57 & 0.22 & 1.23 & 1.51 & 0.33 & 1.16 \\
\hline $\mathrm{NO}_{2}(\mathrm{ppm})$ & 23 & 133 & 54.83 & 5.84 & 32.01 & 24.90 & 1.21 & 1.01 \\
\hline $\mathrm{H}_{2} \mathrm{~S}(\mathrm{ppm})$ & 21 & 476 & 150.73 & 31.79 & 74.12 & 20.20 & 1.12 & -0.52 \\
\hline $\mathrm{HCs}(\mathrm{ppm})$ & 222 & 600 & 335.50 & 19.55 & 47.13 & 77.01 & 1.17 & 0.26 \\
\hline
\end{tabular}

in Lahore are generated by diesel buses, two-stroke rickshaws and broken roads. Main air pollutants include particulate matter and nitrogen dioxide $[11,20]$.

The descriptive statistical data was applied to the emissions data of motorcycles and cars. The range of minimum and maximum with mean of data were calculated along with standard error, standard deviation, variance, skewness, kurtosis was also calculated and results are presented in Tables 3 and 4.

\section{Conclusion}

Traffic jamming problem and uncontrolled vehicle emissions make life miserable, causing threat to human health and economic loss. Public transport service and air quality situation of Lahore is continuously declining every year and imposing huge cost on hospitalization. Government is trying to improve to set up a new transport system but this system is on only one route of about $30 \mathrm{~km}$ (metro route). Although there is little information on human health, but it is clear evidence that the air quality in Lahore is harmful for the city inhabitants and it is causing not only uneasiness but also several diseases including asthma and allergy. Policy makers should address this problem immediately. Automobile emissions are a major contributor to air pollution; it is possible to improve air quality by reducing the vehicular emissions through improving the public transport system. Government should strengthen vehicle emission standards, implementations of regulations and measures to reduce fuel demand and improvement in traffic conditions. The provincial government is trying to improve public transport facilities of the city through orange line transport system, which take about 2 years to complete. The authors suggestion to the provincial and local government to increase the tree plantation in the Lahore city. The orange line transport system will solve the transport problem and tree plantation will reduce the congestion problems, as well as improve the air quality.

\section{CONFLICT OF INTEREST}

The authors declare that there is no conflict of interests regarding the publication of this article.

\section{REFERENCES}

1. World Ambient, 2015. Fact sheet N 313. Updated March, (2014).

2. P. Bielaczyc, J. Woodburn, A. Szczotka and P. Pajdowski, Energy Procedia, 66, 21 (2015);

https://doi.org/10.1016/j.egypro.2015.02.011

3. Bureau of Statistics, Punjab, Pakistan (2011)

4. A. Chan, W. Isaacman, G. Wilson, K.R. Worton, D.R. Ruehl, C.R. Nah, T. Gentner, D.R. Dallmann, T.R. Kirchstetter, T.W.R.A. Harley, J.B. Gilman, W.C. Kuster, J.A. de Gouw, J.H. Offenberg, T.E. Kleindienst, Y.H. Lin, C.L. Rubitschun, J.D. Surratt, P.L. Hayes, J.L. Jimenez and A.H. Goldstein, J. Geophys. Res. Atmos., 118, 6783 (2013); https://doi.org/10.1002/jgrd.50533.

5. I. Colbeck, Z.A. Nasir, S. Ahmad and Z. Ali, Aerosol Air Qual. Res., 11, 689 (2011); https://doi.org/10.4209/aaqr.2010.10.0087.

6. F.J. Kelly and J.C. Fussell, Environ. Geochem. Health, 37, 631 (2015); https://doi.org/10.1007/s10653-015-9720-1.

7. B. Ghauri, A. Lodhi and M. Mansha, Environ. Monit. Assess., 127, 237 (2007);

https://doi.org/10.1007/s10661-006-9276-8.

8. Government of Punjab, Planning and Development Punjab, Pakistan. (2014). 
9. R. Hameed, N.A. Bhatti, O. Nadeem, S. Haydar and M.A. Khan, J. Pak. Instit. Chem. Eng., 41, 59 (2013).

10. S.R. Hasan, N. Paul, P. Halder, M. Alam, M. Raquib, M. Islam and M. Khan, Global J. Sci. Front. Res., 13, 51 (2013).

11. Z.A. Jafary and I.A. Faridi, Pak. J. Physiol., 2, 31 (2006).

12. D. Loomis, Y. Grosse, B. Lauby-Secretan, E.L. Ghissassi, F. Bouvard, L. Benbrahim-Tallaa, N. Guha, R. Baan, H. Mattock and K. Straif, Lancet Oncol., 14, 1262 (2013); https://doi.org/10.1016/S1470-2045(13)70487-X

13. HEI International Scientific Oversight Committee, Outdoor Air Pollution and Health in the Developing Countries of Asia: A Comprehensive Review, Special Report 18, Health Effects Institute, Boston, MA (2010)

14. Z.S. Mirza, S. Muhammad, M.A. Beg and I. Malik, Pak. J. Zool., 45, 679 (2013)
15. MRU Delta, Operation Mannual VI, vol. 1, p. 29 (2000).

16. C.A. Pope III, M. Ezzati and D.W.N. Dockery, Engl. J. Med., 360, 376 (2009); https://doi.org/10.1056/NEJMsa0805646.

17. E. Sanchez-Triana, S. Enriquez, J. Afzal, A. Nakagawa and A.S. Khan, Cleaning Pakistan's Air : Policy Options to Address the Cost of Outdoor Air Pollution (English), World Bank Publications (2014).

18. J. Sharaf, Int. J. Eng. Res. Appl., 3, 947 (2013).

19. T. Wallington and P. Wiesen, Atmos. Environ., 94, 258 (2014); https://doi.org/10.1016/j.atmosenv.2014.05.018.

20. Y.W. Park, The Environment and Climate Change Outlook of Pakistan, United Nations Environment Programme (UNEP), p. 107 (2013). 